\title{
Effect of Quarry Waste on Self-Compacting Concrete Containing Binary Cementitious Blends of Fly Ash and Cement
}

\author{
Baboo Rai, ${ }^{1}$ Sanjay Kumar, ${ }^{1}$ and Kumar Satish ${ }^{2}$ \\ ${ }^{1}$ Department of Civil Engineering, National Institute of Technology Patna, Bihar, India \\ ${ }^{2}$ Department of Civil Engineering, Birla Institute of Technology Patna, Bihar, India \\ Correspondence should be addressed to Baboo Rai; baboo.rai@gmail.com
}

Received 12 May 2016; Revised 7 June 2016; Accepted 20 June 2016

Academic Editor: Giorgio Pia

Copyright (c) 2016 Baboo Rai et al. This is an open access article distributed under the Creative Commons Attribution License, which permits unrestricted use, distribution, and reproduction in any medium, provided the original work is properly cited.

\begin{abstract}
This paper presents the results of the experimental work conducted to study the effect of quarry waste on self-compacting concrete containing binary cementitious blends of fly ash and cement. For this purpose nine trial mixes were prepared, where the percentage replacement of river sand by quarry waste was $0 \%, 10 \%, 20 \%, 30 \%, 40 \%, 50 \%, 70 \%$, and $100 \%$ to study the flowability characteristics of SCC. In all, 108 cube samples and 54 cylindrical samples were cast to study the strength parameters of SCC with and without quarry waste. The water to binder ratio was maintained at $0.36 \%$ while the dose of chemical admixture was $2.2 \%$ by weight of cement. For all trial mixes the fly ash percentage replacement to cement was kept constant at $30 \%$. Based on the standard flowability test a visual stability index has been provided to all the trial mixes. Quarry waste replacement showed the desirable results that can suggest the usage in self-compacting concrete as well as in normally vibrated concrete.
\end{abstract}

\section{Introduction}

Concrete that flows and settles due to its own weight without segregation and bleeding is called self-compacting concrete (SCC) [1]. According to Okamura and Ouchi $[1,2]$ SCC has several advantages over normally vibrated conventional concrete. It can flow with ease in congested reinforcement at beam column junctions. SCC improves the durability of concrete structures. In SCC, no vibration is required for the compaction. It flows like "honey" and after placing it has a very smooth surface. The visual stability index (VSI) [3] of SCC can be defined by four key parameters: flowability, passing ability, viscosity, and segregation resistance. In recent years, SCC has gained wider applications as it reduces the time period of construction. Furthermore, with the development in the field of superplasticizers technology this concrete type has become widespread all over the world [4-6].

In recent times quarry wastes as fine aggregate have gained attention as concreting material to be used in construction [7]. Limited research has been conducted in the area of flowing concrete (SCC) incorporating quarry waste as a partial or full replacement to river sand. Using quarry waste in SCC is expected to provide significant economic benefits to concrete producers. Ho et al. [8] utilized quarry waste in SCC as a partial replacement of cementing material and reported that the use of higher water cement ratio demands high cement content for a required strength. Khatib [9] concluded that when fine recycled aggregates were used as a partial replacement to natural fine aggregates in concrete and when the free water/cement ratio was kept constant for all the mixes, the 28-day strength of the concrete developed at a slower rate as compared to reference mix. Kou and Poon [10] studied the fresh and hardened properties of SCC with recycled concrete aggregates as both coarse and fine aggregates states. Three sets of SCC mixes with partial replacement of recycled fine aggregate with river sand were prepared and the percentage of coarse recycled aggregates was fixed at $100 \%$. The cement content was kept constant for all concrete mixtures. They concluded that the compressive strength of crushed fine sand concrete decreased when compared with the control mixes at 75 and $100 \%$ replacement levels and further concluded that the slump decreases with an increase in crushed fine sand content. Evangelista and de Brito 2010 [11] indicated that the use of fine recycled concrete aggregates up to $30 \%$ replacement ratios will have minimal effect on the mechanical properties of concrete. Celik and 
Marar and Nagaraj and Banu $[12,13]$ in their research on replacement of river sand with quarry waste in normally vibrated concrete revealed that at higher percentage level of replacement there is a loss in compressive strength of concrete as well as in slump value. De Silva et al. 2007 [14] reported that there is gain in strength of concrete containing quarry waste as it has a rough shape and angular particles which imparts better interlocking. The quantity of cement increases because the use of quarry waste has been reported. The quarry wastes contain about $20 \%$ more fines smaller than the $200 \mu \mathrm{m}$ sieve when compared with $5 \%$ for river sand. Ilangovan et al. 2008 [15] concluded that when compared to conventional concrete the workability value of quarry waste concrete decreases. However, the water absorption of concrete made of quarry waste is more than that of concrete made with natural aggregates.

The use of fly ash in concrete in most advantageous proportion has many benefits and improves concrete properties in both fresh and hardened state. In SCC fly ash provides cohesiveness to the mix. Efforts have been made to quantify the effect of fly ash in concrete by determining the cementing efficiency factor ( $k$-value) for fly ash. The $k$-value according to Smith 1967 [16] is defined as the part of the pozzolanic material which can be considered as equivalent to Portland cement having the same properties as concrete without the pozzolanic material. Many researchers [17-20] have observed that the $k$-value of fly ash with respect to 28 days of compressive strength varies over a wide range depending upon amount of fly ash added in the mix, water cement ratio, age of concrete, and type of cement.

Oneffect of quarry waste in binary cementitious blends of fly ash, Siddique in 2000 [21] reported that with the use of fly ash as a cementitious material the quantity of water required in concrete mix was less and attributed to the fact that the fly ash particles when they come in contact with cement alter the flocculation of cement. Furthermore, the shape and texture of fly ash particles enhance the workability of the concrete mixes containing quarry waste. Raman et al. in 2004 [22] concluded that the use of quarry waste in concrete causes reduction in workability and hence increases in the quantity of cement required whereas the use of fly ash in concrete offers improved workability and reduction in cement content. Naidu et al. [23] have investigated that the quarry waste concrete incorporating 30\% fly ash as binder exhibited the highest compressive strength and pull-out force in all conditions. Through the limited literature available it can be concluded that the concomitant use of quarry waste as an inert material and fly ash as cementitious material may lead to negation of some undesirable effect of each constituent material.

In the present investigation, fly ash, a supplementary cementitious material with a $k$-value of 0.55 , is used to improve the mechanical characteristics of SCC made with quarry waste as fine aggregate. Furthermore, the concomitant use of quarry waste as fine aggregate with fly ash as cementitious material in concrete will lead to the profits of using such materials and will simultaneously result in the production of cost-effective SCC mixes which will also have ecological benefits.

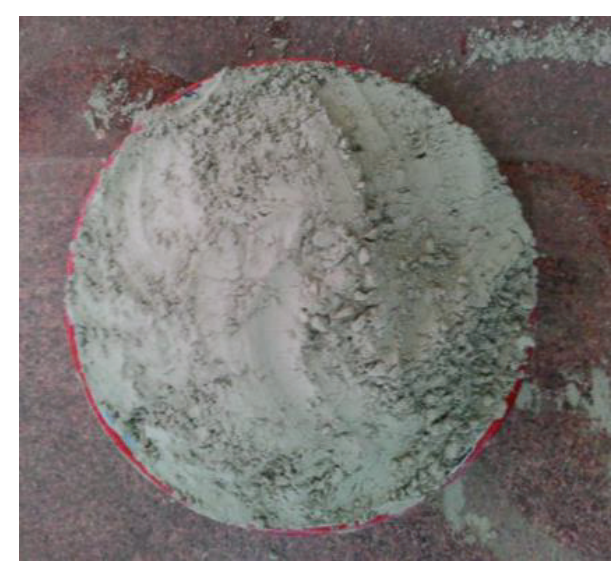

Figure 1: Fly ash sample.

\section{Material Properties}

The materials used for the experimental program were locally available at the institute through the construction agencies working in the institute.

2.1. Cementitious Material. The cement used was Jaypee Ordinary Portland Cement (OPC) of grade 43 conforming to IS 8112-1989 [24]. The various laboratory tests conforming to IS, 4031-1996 (Parts 1 to 15) [25], specification were carried out to test the physical properties of cement. Low calcium fly ash samples were taken from Kahalgaon Thermal Power Plant, and NTPC were used in this study as a replacement to cement. Fly ash shown in Figure 1 was not processed and was used as received. The sample satisfied the requirements of IS 3812 (Part I) [26]. The physical properties of cement and fly ash are presented in Table 1 while chemical properties are supplied by the Kahalgaon Thermal Power Plant; NTPC is presented in Table 2.

2.1.1. Characterization of Fly Ash and OPC. Mineralogical structures of fly ash with X-ray diffraction (XRD) were investigated. Fly ash sample is powdered by grinding in a pestle and was subjected to XRD analysis using a Rigaku Ultima IV system with $\mathrm{Cu}$ Ka radiation. Scans were run from $20^{\circ}$ to $80^{\circ}$ with increments of $0.05^{\circ}$ and a counting time of $2 \mathrm{~s}$ per step. Graph (Figure 1) is obtained from Origin Pro (Plus) software based on the data of XRD of the samples. The graph is compared with JCPDS charts using the X'pert High score (Plus) software by which we get the quantitative analysis of the specimens. From the XRD analysis of fly ash, it is seen that maximum peak is obtained at $26^{\circ}$. Figure 2 shows XRD pattern of fly ash as generally detected amorphous phase and small crystalline phases as quartz, mullite, and hematite.

Mullite $\left(3 \mathrm{Al}_{2} \mathrm{O}_{3} \cdot 2 \mathrm{SiO}_{2}\right)$ is formed by the aluminum silicate present in fly ash. Furthermore, iron and silica are present in the form of hematite $\left(\mathrm{Fe}_{2} \mathrm{O}_{3}\right)$ and quartz mineral, respectively. Also, when $2 \theta$ is between 20 and $35^{\circ}$ it is seen that the amorphous phase reaches its maximum concluding that amorphous phase has silica-like characteristics since it is close to the maximum peak value of quartz crystal. 
TABLE 1: Physical properties of cement and fly ash.

\begin{tabular}{lccc}
\hline Sl number & Physical properties & Observed value for cement & Observed values for fly ash \\
\hline 1 & Specific gravity & 3.15 & 2.2 \\
2 & Initial setting (minutes) & $30 \mathrm{~min}$ & $45 \mathrm{~min}$ \\
3 & Final setting (minutes) & $600 \mathrm{~min}$ & $280 \mathrm{~min}$ \\
4 & Consistency $(\%)$ & $30 \%$ & 35 \\
5 & Fineness $\left(\mathrm{m}^{2} / \mathrm{kg}\right)$ & 225 & 368 \\
\hline
\end{tabular}

TABLE 2: Chemical properties of fly ash.

\begin{tabular}{lccc}
\hline $\begin{array}{l}\text { Sl } \\
\text { number }\end{array}$ & Test conducted & $\begin{array}{c}\text { Observed } \\
\text { values (\%) }\end{array}$ & $\begin{array}{c}\text { Requirement as } \\
\text { per IS 3812 (Part } \\
\text { I), 2003, } \\
\text { reaffirmed: 2013 }\end{array}$ \\
\hline 1 & Loss of ignition & 2.53 & $5.0(\max )$ \\
2 & ${\text { Silica as } \mathrm{SiO}_{2}}_{2}$ & 59.51 & $35(\mathrm{~min})$ \\
3 & $\mathrm{SiO}_{2}+\mathrm{Al}_{2} \mathrm{O}_{3}+\mathrm{Fe}_{2} \mathrm{O}_{3}$ & 86.85 & $70(\min )$ \\
4 & ${\mathrm{Available} \mathrm{alkalis} \mathrm{as} \mathrm{Na}_{2} \mathrm{O}}_{5}$ & 0.43 & $1.5(\max )$ \\
6 & Reactive silica & 29.32 & $20(\min )$ \\
7 & Magnesium as $\mathrm{MgO}$ & 1.97 & $5.0(\max )$ \\
8 & Sulphate as $\mathrm{SO}_{3}$ & 2.07 & $3.0(\max )$ \\
9 & Total chloride & 0.032 & $0.05(\max )$ \\
\hline
\end{tabular}

TABLE 3: Physical properties of quarry waste and natural sand.

\begin{tabular}{lcc}
\hline Physical properties & Quarry waste & River sand \\
\hline Specific gravity & 2.73 & 2.66 \\
Fineness modulus & 2.46 & 2.60 \\
Water absorption & 5.9 & 1.35 \\
\hline
\end{tabular}

In a similar fashion crystallography of ordinary Portland cement was analyzed using XRD and is shown in Figure 3. The XRD pattern of Portland cement shows peaks similar to $\mathrm{C}_{3} \mathrm{~S}$ (alite), $\mathrm{C}_{2} \mathrm{~S}$ (belite), $\mathrm{C}_{3} \mathrm{~A}$ (tricalcium aluminate), and $\mathrm{C}_{4} \mathrm{AF}$ (brownmillerite).

2.2. Fine Aggregates. Ordinary sand from river Sone having fineness modulus of 2.60 was used as natural fine aggregate. Sand after sieve analysis conforms to zone III as per IS 3831970 [27]. Quarry waste was made available locally from Gammon India and was used as replacement of natural fine aggregate. The physical properties for the quarry waste and river sand as found through laboratory test are presented in Table 3. The sample of quarry waste is shown in Figure 4. Quarry waste after sieve analysis conforms to zone III as per IS 383-1970. Figure 5 shows the particle size distribution of river sand and quarry waste.

2.3. Coarse Aggregate. Locally available crushed igneous rocks from Pakur with $16 \mathrm{~mm}$ graded size have been used as coarse aggregate. The physical properties for the coarse aggregate as found through laboratory test are as follows:

Aggregate crushing value $=24 \%$.



FIGURE 2: XRD traces of FA; Q: quartz; M: mullite; H: hematite.

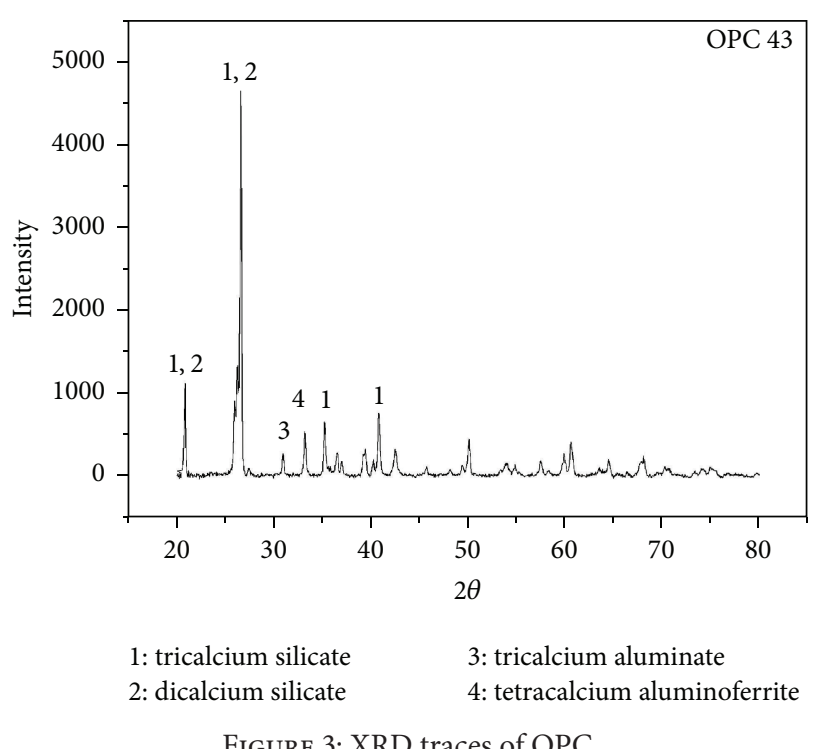

Aggregate impact value $=29 \%$.

Specific gravity $=2.713$.

Water absorption $=0.755$.

The particle size distribution of the locally available coarse aggregate is shown in Figure 6.

2.4. Chemical Admixtures. Polycarboxylic ether based high range water reducing (HRWR) admixture with inbuilt Viscosity Modified Admixture (VMA) supplied by BASF India limited with a brand name of Master Glenium SKY 8632 has 


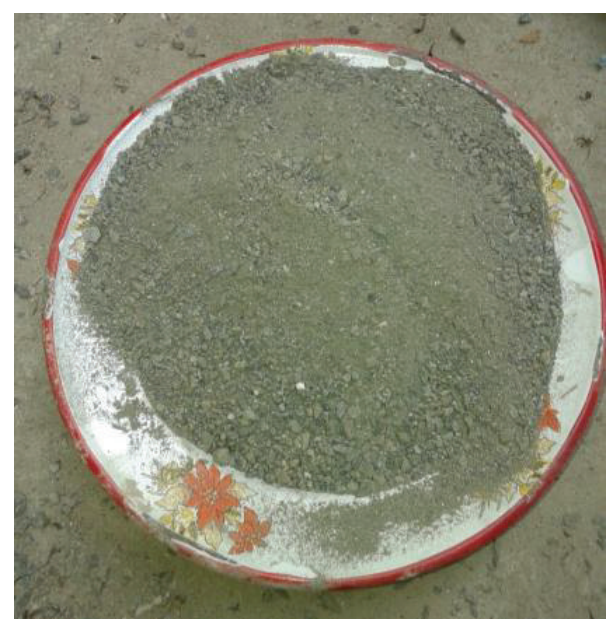

Figure 4: Quarry waste sample.

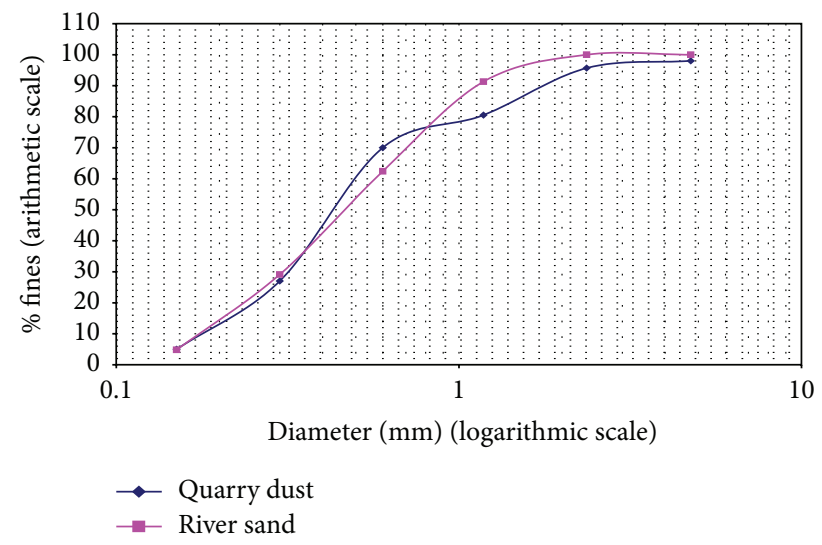

FIGURE 5: Particle size distribution of river sand and quarry waste.

TABle 4: Properties of chemical admixture.

\begin{tabular}{lc}
\hline Colour & Light brown liquid \\
Relative density & $1.08 \pm 0.01$ at $25^{\circ} \mathrm{C}$ \\
$\mathrm{pH}$ & $\geq 6$ at $25^{\circ} \mathrm{C}$ \\
Chloride ion content & $<0.2 \%$ \\
\hline
\end{tabular}

been used in the present research work. The properties as obtained from the manufacturer are given in Table 4 .

2.5. Mix Proportioning. Nine trial mixes were prepared, where the percentage replacement of river sand by quarry waste was $10 \%, 20 \%, 30 \%, 40 \%, 50 \%, 70 \%$, and $100 \%$ by mass. For comparison of results two reference mixes were prepared and cast in which quarry waste percentage was nil. The dose of chemical admixture was $2.2 \%$ by weight of cement for all trial mixes while the fly ash percentage replacement to cement was kept constant at 30\%. In all, 108 cube samples and 54 cylindrical samples were cast to study the strength parameters.

For incorporating fly ash in concrete, there is no theoretical background given in code. A guideline in the form of

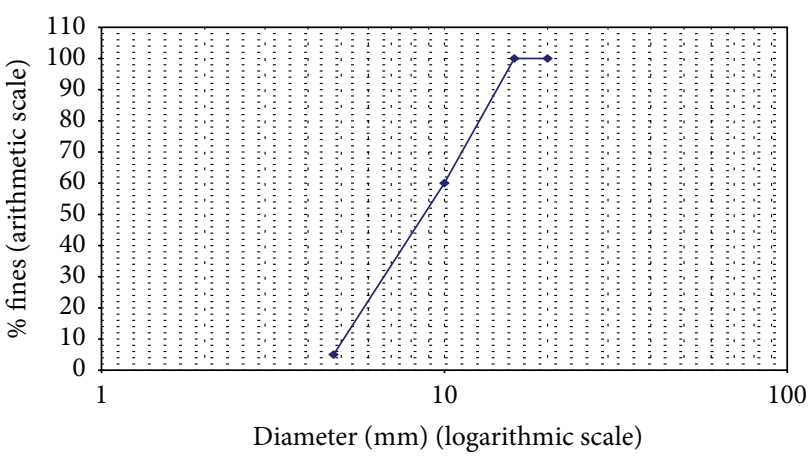

Figure 6: Particle size distribution of coarse aggregate.

numerical example has been incorporated in IS 10262-2009 [28] where the total binder content is increased arbitrarily. However, in the present work, for the same water-to-cement ratio, the strength of fly ash concrete is comparable with that of conventional concrete without fly ash; a cementing efficiency factor for fly ash has been taken into account which can be represented as

$$
\frac{w}{C}=\frac{w}{C_{1}+k f},
$$

where $w$ is water content, $C$ is cement content of control concrete, $C_{1}$ is cement content of fly ash concrete, $f$ is fly ash content, and $k$ is cementing efficiency factor.

Here in this research the cementing efficiency factor $(k)$ of 0.55 has been considered for fly ash as the lubricating action of fly ash reduces water requirement and hence drying shrinkage. The cementing efficiency factor $(k)$ for fly ash has been reported to vary from 0.3 to 0.6 [17-20]. The water to powder ratio for all the mixes was fixed at 0.36 . The mix proportioning for all nine trial mixes is substantiated in Table 5.

As water adsorption for coarse aggregate, fine aggregate, and quarry waste has been considered for casting, therefore extra water was added in the mix to convert the aggregates into saturated surface dry condition. This extra water is not going to participate in the reaction mechanism of concrete and hence is not considered in the $\mathrm{w} / \mathrm{b}$ ratio.

\section{Results and Discussions}

3.1. Flowability Test Results. The various flowability tests conducted in lab were as per EFNARC [29] and the tests conducted were slump flow test, J-ring test, L-box test, and $\mathrm{V}$-funnel test. The results of the slump flow tests of fly ash induced SCC with quarry waste as fine aggregate are presented in Table 6 and comparative study with varying percentage of quarry waste is shown graphically through Figures 7-9. The slump flow varied between the ranges of $670-725 \mathrm{~mm}$. A minimum slump flow of $650 \mathrm{~mm}$ is generally recommended for SCC.

3.1.1. Effect of Quarry Waste on Flowability Index. The spread diameter decreases with increase in replacement level of 
TABLE 5: Mix proportions for $1 \mathrm{~m}^{3}$ concrete.

\begin{tabular}{lccccccccc}
\hline Mix number & $\begin{array}{c}\text { Cement } \\
(\mathrm{kg})\end{array}$ & $\begin{array}{c}\text { Fly ash } \\
(\mathrm{kg})\end{array}$ & $\begin{array}{c}\text { Water/binder } \\
\text { ratio }\end{array}$ & $\begin{array}{c}\text { Coarse agg } \\
(\mathrm{kg})\end{array}$ & $\begin{array}{c}\text { River sand } \\
(\mathrm{kg})\end{array}$ & $\begin{array}{c}\text { \% quarry } \\
\text { waste by wt } \\
\text { of sand }\end{array}$ & $\begin{array}{c}\text { \% HRWR \& } \\
\text { inbuilt VMA }\end{array}$ & $\begin{array}{c}\text { Water (liter) } \\
(\text { liter) }\end{array}$ \\
\hline 1 & 468 & 0 & 0.36 & 878.86 & 918.7 & 0 & 2.2 & 168.48 & 19.26 \\
2 & 390.8 & 139 & 0.36 & 805.30 & 831.1 & 0 & 2.2 & 191 & 18.9 \\
3 & 390.8 & 139 & 0.36 & 792.3 & 754.9 & 10 & 2.2 & 191 & 22.76 \\
4 & 390.8 & 139 & 0.36 & 790.1 & 671.6 & 20 & 2.2 & 191 & 26.85 \\
5 & 390.8 & 139 & 0.36 & 792.3 & 591.9 & 30 & 2.2 & 191 & 30.8 \\
6 & 390.8 & 139 & 0.36 & 791.3 & 509.8 & 40 & 2.2 & 191 & 34.67 \\
7 & 390.8 & 139 & 0.36 & 792.3 & 428.9 & 50 & 2.2 & 191 & 38.58 \\
8 & 390.8 & 139 & 0.36 & 792.3 & 265.9 & 70 & 2.2 & 191 & 46.09 \\
9 & 390.8 & 139 & 0.36 & 792.3 & 0 & 100 & 2.2 & 191 & 59.04 \\
\hline
\end{tabular}

TABLE 6: Flowability test results.

\begin{tabular}{|c|c|c|c|c|c|c|c|c|c|}
\hline $\begin{array}{l}\text { Mix } \\
\text { number }\end{array}$ & $\%$ fly ash & $\begin{array}{l}\% \text { quarry } \\
\text { waste }\end{array}$ & $\begin{array}{c}\text { Max spread } \\
\text { dia in } \mathrm{mm}\end{array}$ & $\begin{array}{c}\text { Time to reach } \\
\text { max spread } \\
(\mathrm{sec})\end{array}$ & $\begin{array}{c}T_{500} \text { time in } \\
\text { sec }\end{array}$ & $\begin{array}{l}\text { J-ring } T_{500} \\
\text { time in sec }\end{array}$ & $\begin{array}{c}H_{2} / H_{1} \text { blocking } \\
\text { ratio }\end{array}$ & V-funnel time & VSI \\
\hline 1 & 0 & 0 & 652 & 6.5 & 3.5 & 5.6 & 0.82 & 11.6 & 1 \\
\hline 2 & 30 & 0 & 705 & 4.2 & 3 & 6 & 0.88 & 10.8 & 1 \\
\hline 3 & 30 & 10 & 724 & 6.8 & 2.8 & 3.1 & 0.8 & 9.8 & 1 \\
\hline 4 & 30 & 20 & 710 & 7.8 & 3 & 3.8 & 0.8 & 10.4 & 0.5 \\
\hline 5 & 30 & 30 & 700 & 8.4 & 2 & 2.6 & 0.9 & 9.4 & 0.5 \\
\hline 6 & 30 & 40 & 695 & 10 & 2.4 & 4.1 & 0.8 & 10 & 0.5 \\
\hline 7 & 30 & 50 & 690 & 10.2 & 2 & 4.8 & 0.86 & 10.6 & 1 \\
\hline 8 & 30 & 70 & 680 & 10.4 & 1.9 & 5 & 0.85 & 10.4 & 1 \\
\hline 9 & 30 & 100 & 660 & 10 & 3.24 & 5.4 & 0.84 & 10.5 & 1 \\
\hline
\end{tabular}

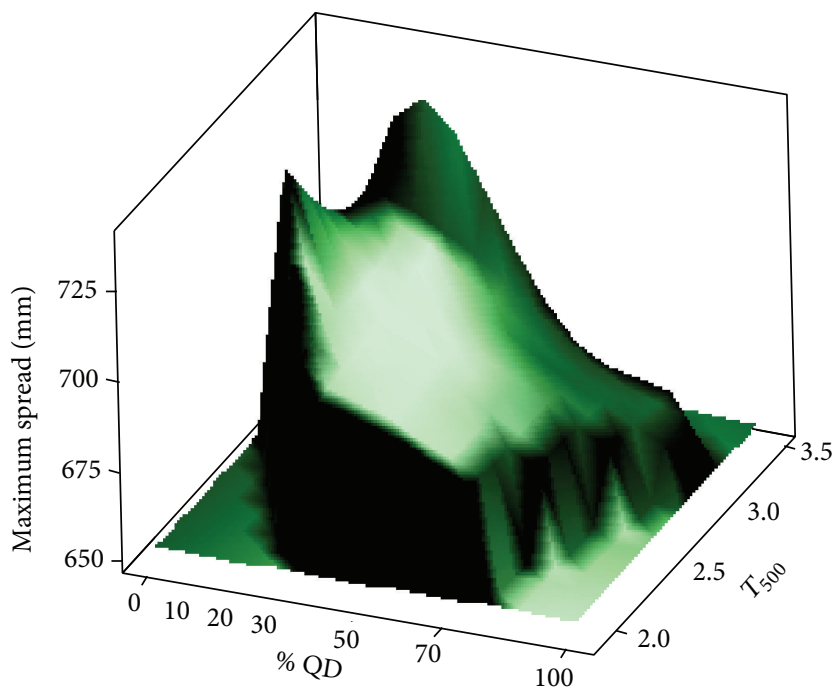

FIGURE 7: Surface plot of maximum spread, \% quarry waste, and $T_{500}$ time.

quarry waste in fine aggregate. The blocking ratio and $\mathrm{V}$ funnel time were almost consistent at all replacement levels. However, beyond 50\% replacement level, the V-funnel time increased. The decrease in spread and increase in V-funnel

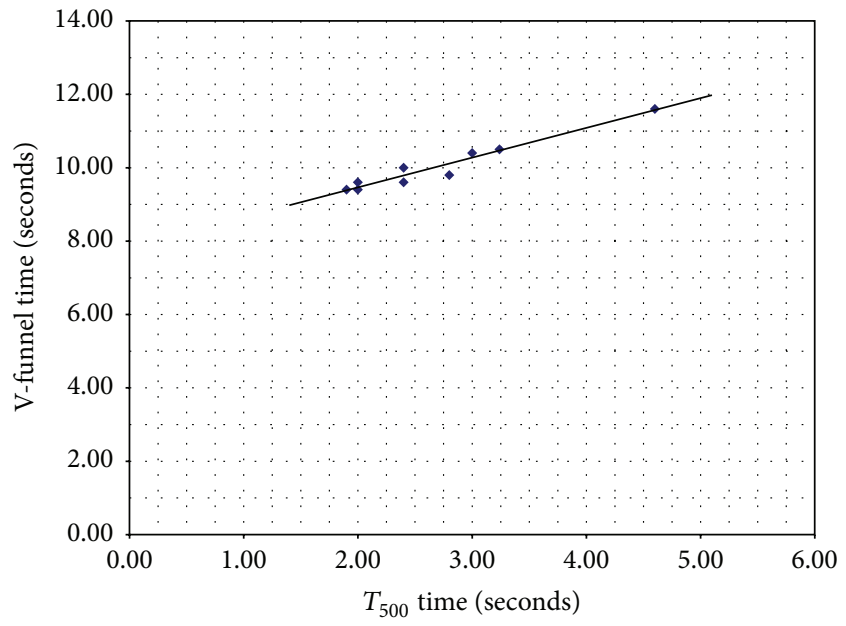

FIgURE 8: $T_{500}$ time versus $V$-funnel time.

time at higher percentage of quarry waste are again attributed to the fact that there is reduction in the free water content in the SCC mix due to high water absorption of quarry waste. The increase of water demand of concrete mixtures produced by the adverse effects of texture and shape of quarry waste is minimized by using HRWR with inbuilt VMA. 


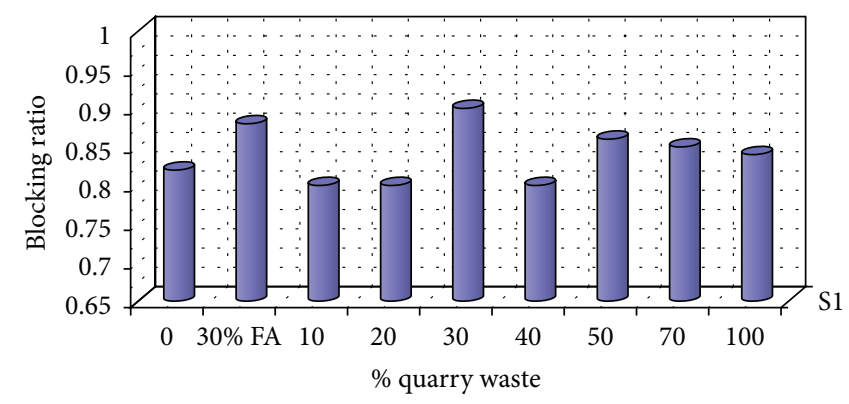

FIGURE 9: Blocking ratio versus \% quarry waste.
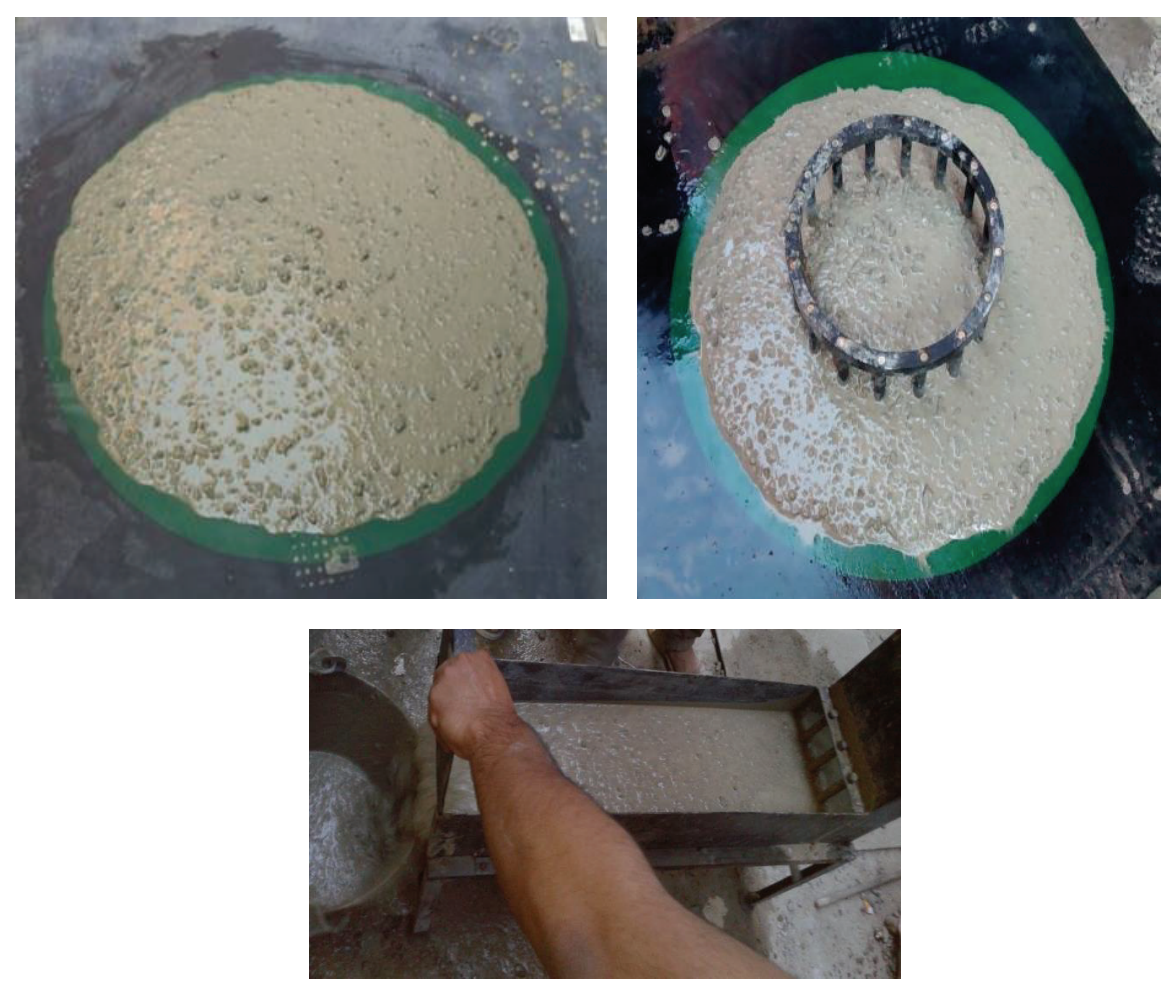

FIGURE 10: VSI rating for mixes with quarry waste.

From the flowability test results presented in Table 6, it can be observed that the slump flow time varied from 6.8 to $10.4 \mathrm{sec}$ for maximum spread. Furthermore, the results of Lbox and $\mathrm{V}$-funnel test were consistent. The effect of quarry waste as fine aggregate on the flowability of SCC is evident from Figure 7 which represents the surface plot of maximum spread, \% quarry waste, and $T_{500}$ time. From the figure it can be concluded that, at $30 \%$ replacement of fine aggregate by quarry waste, the slump flow and the J-ring flow were observed to be consistent. In all the SCCs mixes with quarry waste as fine aggregate, no segregation and bleeding were observed and this may be due to presence of fly ash. Moreover, all the four flowability tests were within the acceptable limits of EFNARC [29].

Furthermore, the presence of fly ash has no significant effect on the flowing ability of both the SCC mixes. This may be due to round particle shape of fly ash and moreover, fly ash generally does not increase the water demand [30]. However bleeding and segregation were negated by the presence of fly ash in all the SCC mixes. The same has been reported by Tangchirapat et al. [31] for the case of SCC with recycled concrete aggregate.

3.1.2. Visual Stability Index. SCC is also characterized by visual stability index of the mixture apart from flowability index. This test is subjective and gives only the qualitative measure of fresh concrete ability to resist segregation [3]. Furthermore, this test is relatively used to compare several similar SCC mixes. The VSI rating varies from 0 to 3. A rating of 0 means no evidence of segregation and bleeding and 3 means clear evidence of segregation and bleeding.

Figure 10 represents the visuals of SCC mixes with quarry waste as fine aggregate. At 30\% replacement of river sand with quarry waste no mortar halo in the slump flow patty was observed; however, a slight evidence of bleed or air popping on the surface of SCC was observed and hence a VSI rating of 


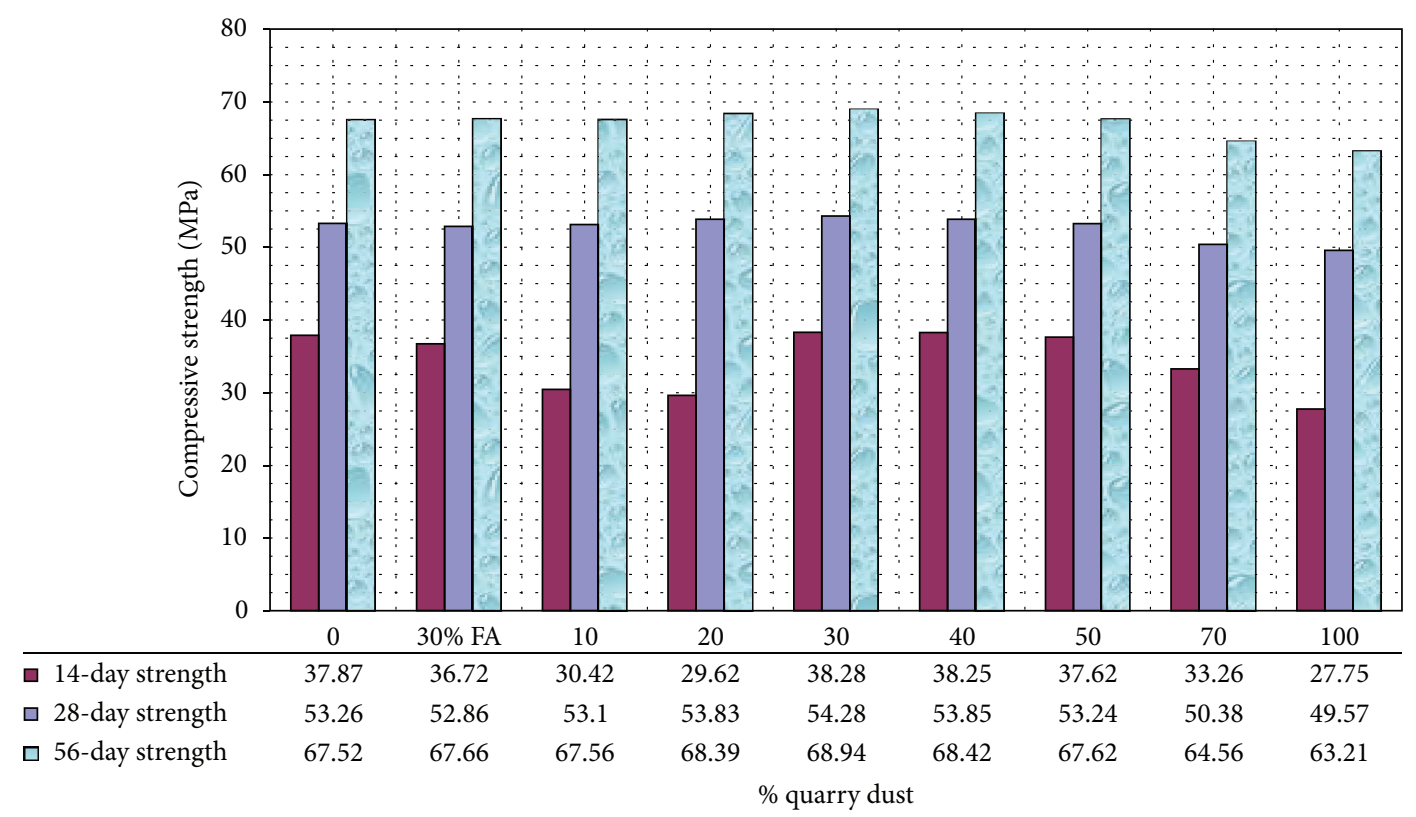

Figure 11: Compressive strength test results.



FIGURE 12: \% increase or decrease in compressive strength.

0.5 was given to this trial mix. At $70 \%$ and $100 \%$ replacement a slight aggregate pile in the slump flow patty was observed along with evidence of slight bleeding. The VSI rating for all trial mixes is presented in Table 6. However the flowability index was maintained due to the addition of HRWR with inbuilt VMA in the mix.

3.2. Compressive Strength Test Results. Cube specimens prepared for compressive strength were tested in laboratory and different crushing strengths were found. Four cube specimens were broken every 14,28 , and 56 days and the mean values of the four samples were recorded and are substantiated in data table attached with Figure 11. Figure 12 represents the percentage change in compressive strength at both 28 and 56 days with reference mix.
Examining the strength at 28 and 56 days of SCC mixes with quarry waste content from $0 \%$ to $20 \%$ has caused increase in compressive strength by $1 \%$ as compared to reference mix. But when the quarry waste replacement was increased to $30 \%$, the compressive strength increase was almost $2 \%$ at 56 days. As inferred from Figure 12, with an increase in quarry waste content from $30 \%$ to $50 \%$, the reduction in compressive strength was minimal but as the percentage replacement of quarry waste with river sand increased to $100 \%$ the loss in compressive strength was about $7 \%$ at 28 days as well as at 56 days when compared to the reference mix without quarry waste. This may be accredited to the fact that the surface area of the quarry waste requires more cement than natural fine aggregate to cover the surface.

It should be noted however that, in contrast to the results obtained herein, in case of normally vibrated concrete, 


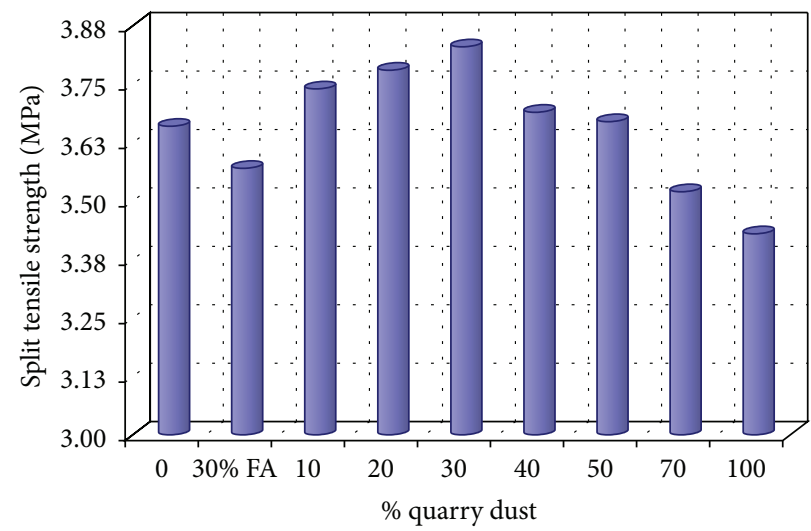

FIGURE 13: Split tensile strength test results.

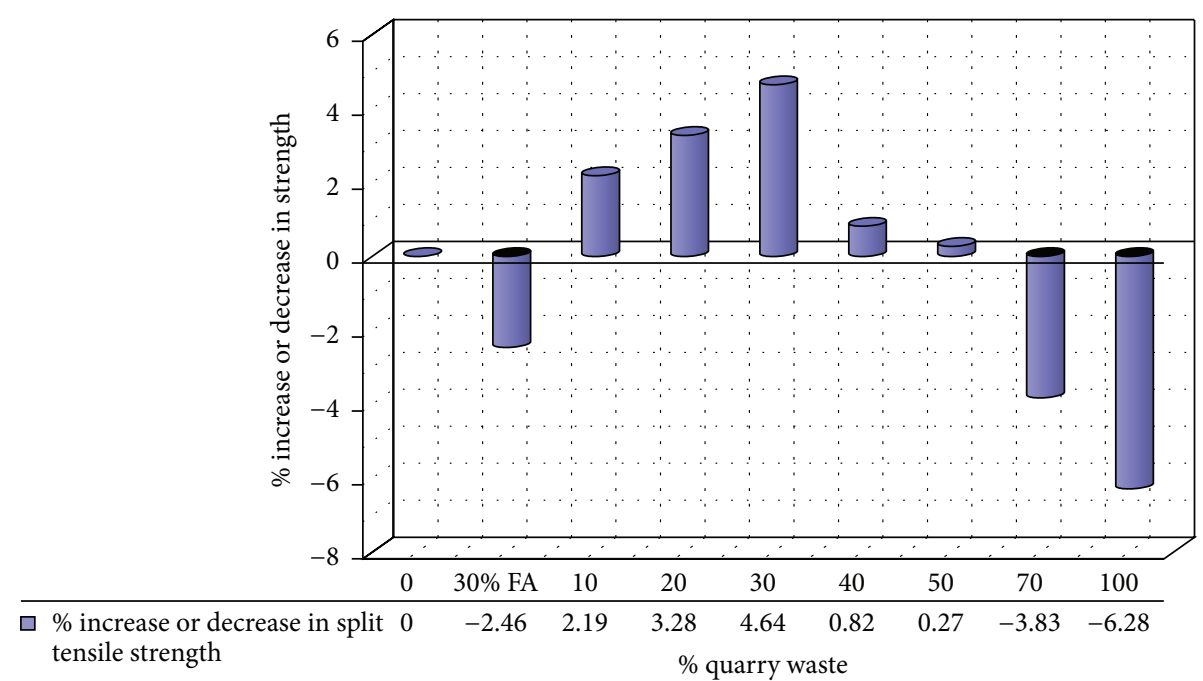

FIGURE 14: \% increase or decrease in split tensile strength.

decrease in strength with increase in quarry waste has been reported in earlier studies by Safiuddin et al. [32] and Tan et al. [33]. They also reported that the compressive strength further decreased as the replacement proportion of sand with quarry waste is increased owing to the high portion of flaky particles in the quarry waste sample used which might have caused the detrimental effects to the concrete compressive strength.

In the present investigation for SCC mixes with quarry waste as fine aggregate at low replacement level up to $30 \%$ the gain in strength is minimal while at high replacement level the findings are in line with the earlier researchers.

Going through the results of 56 days of compressive strength the rate of decrement in compressive strength decreased; this may be due to presence of fly ash. Fly ash exhibits very little pozzolanic activity at early age and at later ages the pozzolanic activity of fly ash becomes effective resulting in gain in strength [20]. It can be observed from the results of 56 days (Figure 12) that the negative effects of reduced compressive strength in the quarry waste concrete were compensated by the inclusion of fly ash into the concrete.
3.3. Split Tensile Strength Test Results. The splitting tensile strength of concrete is an important mechanical property that greatly affects the size and extent of tension related failure behavior, such as flexural cracking in beams.

From the graph presented through Figures 13 and 14 it is clear that the splitting tensile strengths of quarry waste SCC mixtures are increasing with increase in quarry waste percentage. The increase is almost $5 \%$ at $30 \%$ replacement while this increment reduced to almost $0.3 \%$ at about $50 \%$ replacement. However, after 50\% replacement level decrement in split tensile strength was observed. At 100\% replacement level the decrement was almost 7\% when compared to reference mix. The reasons may be the same as discussed in previous subsection.

For SCC cylinder splitting, strengths of about 2-6 MPa have been reported in the literature, corresponding to compressive strengths of about 20-80 MPa. However, not much has been reported in literature with regard to splitting tensile strength of SCC mixes with quarry waste as fine aggregate.

Compressive strength of cylindrical test samples was recorded and is shown in Figure 15. A correlation between 28day split tensile and 28-day cylindrical compressive strengths is shown in Figure 16. A linear relationship in the form of 


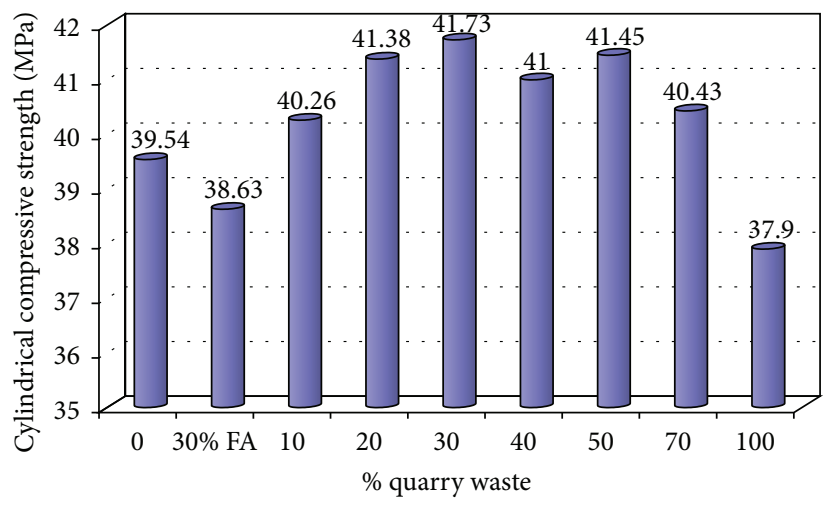

FIGURE 15: Cylindrical compressive strength.

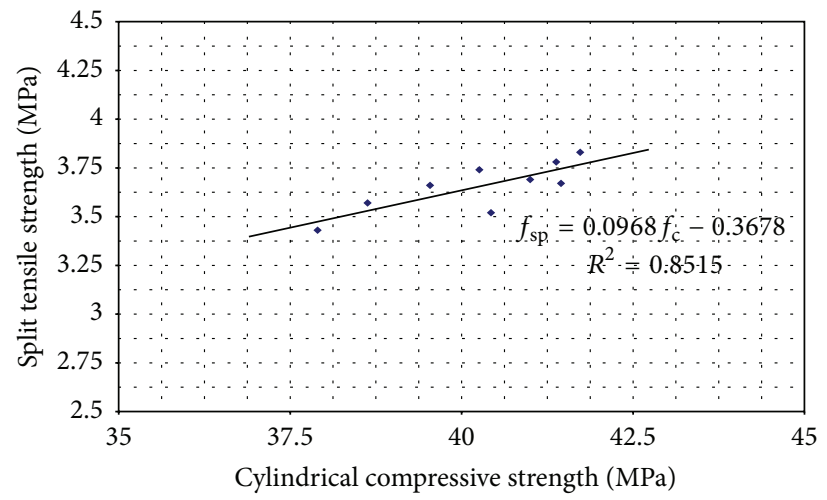

FIGURE 16: Correlation between cylindrical split tensile and compressive strength.
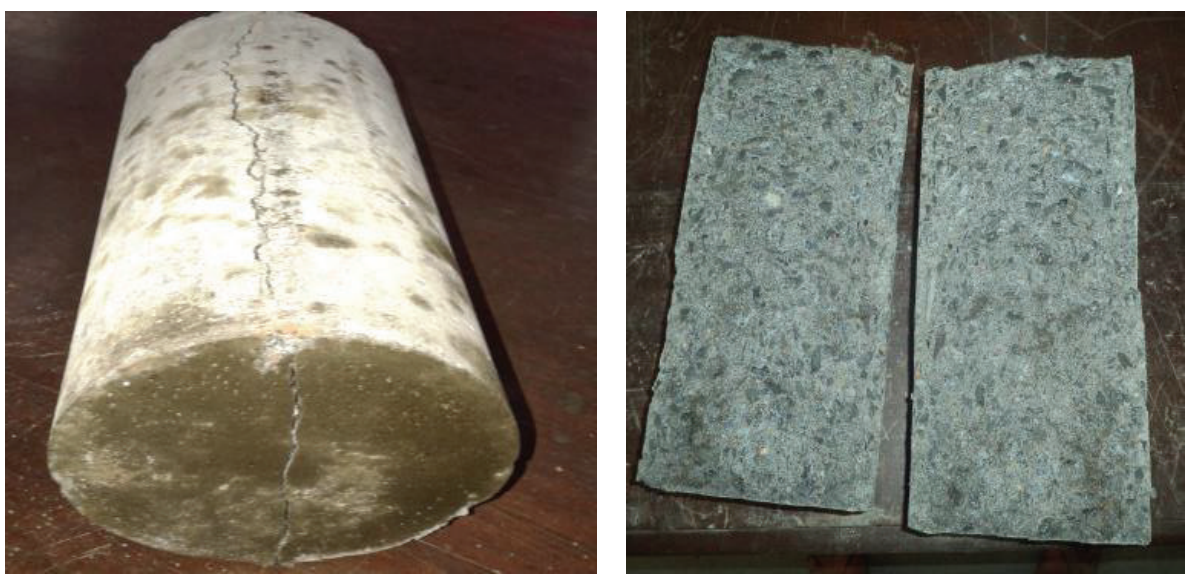

FIGURE 17: Visual of split tensile fracture.

$f_{\text {sp }}=0.968 f_{\mathrm{c}}-0.3678$ has been obtained through regression analysis with $R^{2}$ value of 0.8515 . Here, $f_{\mathrm{sp}}$ and $f_{\mathrm{c}}$ denote the 28-day split tensile and compressive strengths of concrete, expressed in $\mathrm{MPa}$, respectively.

Furthermore, the visual of split tensile fracture surface (Figure 17) indicates that, in SCC, the matrix of cement, coarse aggregate, fine aggregate, fly ash, and quarry waste is homogeneous.
After assessing the evaluated results of both compressive strength and split tensile strength it is found that the rate of increase in compressive stress is less as compared to the split tensile strength. This may be accredited to the fact that the particles of quarry waste are sharp edged which help in providing better interlocking with other constituents of concrete thus resulting in higher splitting strength. 


\section{Conclusions}

From the present investigation and limited observations, on the effect of partial replacement of quarry waste with fine aggregate in SCC mixes containing binary cementitious blends of fly ash and cement, it can be concluded that increase in compressive strength and split tensile strength of SCC mixes may be accredited to the fact that the particles of quarry waste are sharp edged which help in providing better interlocking with other constituents of concrete thus resulting in higher strength. Quarry waste replacement showed the desirable results that can suggest the usage in self-compacting concrete as well as in normally vibrated concrete.

The use of quarry sand is generally limited due to the high cement paste volume needed to obtain an adequate workability of concrete. The increase of water demand of concrete mixtures produced by the adverse effects of shape and texture of quarry sand can be minimized using a high range water reducing admixture. From the experimental results observed, river sand replacement of $30 \%$ with quarry waste is recommended.

The beneficial effects of fly ash in the strength development and durability properties of concrete are widely accepted. The contribution of fly ash to the positive effects in the strength in concrete has been attributed to direct water reduction, the increase in the effective volume of paste in the mix, and its pozzolanic reaction. Besides the effect of chemical reaction, fly ash has a physical effect of improving the microstructure of the hydrated cement paste. Therefore, it is noteworthy to mention that quarry waste can be utilized as partial replacement material to sand, in the presence of fly ash, to produce concrete with fair range of compressive strength.

\section{Competing Interests}

The authors declare that they have no competing interests.

\section{References}

[1] H. Okamura, "Self-compacting high-performance concrete," Concrete International, vol. 19, no. 7, pp. 50-54, 1998.

[2] H. Okamura and M. Ouchi, "Self-compacting concrete: development, present use and future," in Proceedings of the 1st International RILEM Symposium on Self-Compacting Concrete (SCC '99), A. Skarendahl and O. Petersson, Eds., pp. 3-14, RILEM Publications SARL, Stockholm, Sweden, 1999.

[3] M. L. Gambhir, Concrete Technology Theory and Practice, Tata McGraw Hill Education, New York, NY, USA, 5th edition, 2013.

[4] K. H. Khayat, "Workability, testing, and performance of selfconsolidating concrete," ACI Materials Journal, vol. 96, no. 3, pp. 346-353, 1999.

[5] R. Siddique, "Properties of self-compacting concrete containing class F fly ash," Materials and Design, vol. 32, no. 3, pp. 1501-1507, 2011.

[6] K. A. Melo and A. M. P. Carneiro, "Effect of Metakaolin's finesses and content in self-consolidating concrete," Construction and Building Materials, vol. 24, no. 8, pp. 1529-1535, 2010.
[7] B. Rai, S. Kumar, and K. Satish, "Effect of fly ash on mortar mixes with quarry dust as fine aggregate," Advances in Materials Science and Engineering, vol. 2014, Article ID 626425, 7 pages, 2014.

[8] D. W. S. Ho, A. M. M. Sheinn, C. C. Ng, and C. T. Tam, "The use of quarry dust for SCC applications," Cement and Concrete Research, vol. 32, no. 4, pp. 505-511, 2002.

[9] J. M. Khatib, "Properties of concrete incorporating fine recycled aggregate," Cement and Concrete Research, vol. 35, no. 4, pp. 763-769, 2005.

[10] S.-C. Kou and C.-S. Poon, "Properties of concrete prepared with crushed fine stone, furnace bottom ash and fine recycled aggregate as fine aggregates," Construction and Building Materials, vol. 23, no. 8, pp. 2877-2886, 2009.

[11] L. Evangelista and J. de Brito, "Durability performance of concrete made with fine recycled concrete aggregates," Cement and Concrete Composites, vol. 32, no. 1, pp. 9-14, 2010.

[12] T. Celik and K. Marar, "Effects of crushed stone dust on some properties of concrete," Cement and Concrete Research, vol. 26, no. 7, pp. 1121-1130, 1996.

[13] T. S. Nagaraj and Z. Banu, "Efficient utilisation of rock dust and pebbles as aggregates in Portland cement concrete," The Indian Concrete Journal, vol. 70, no. 1, pp. 53-56, 1996.

[14] S. H. Y. I. De Silva, R. K. S. Pushpakumara, R. W. C. N. Rajapaksha, and A. Sathyadasan, "Engineering properties and structural behaviour of concrete," Undergraduate Project Report, Department of Civil and Environmental Engineering, University of Ruhuna, Matara, Sri Lanka, 2007.

[15] R. Ilangovan, N. Mahendran, and K. Nagamani, "Strength and durability properties of concrete containing quarry rock dust as fine aggregate," ARPN Journal of Engineering and Applied Sciences, vol. 3, no. 5, pp. 20-26, 2008.

[16] I. A. Smith, "The design of fly-ash concretes," Proceedings of the Institution of Civil Engineers, vol. 36, no. 4, pp. 769-790, 1967.

[17] D. W. S. Ho and R. K. Lewis, "Effectiveness of fly ash for strength and durability of concrete," Cement and Concrete Research, vol. 15, no. 5, pp. 793-800, 1985.

[18] M. K. Gopalan and M. N. Haque, "Mix design for optimal strength development of fly ash concrete," Cement and Concrete Research, vol. 19, no. 4, pp. 634-641, 1989.

[19] A. L. A. Fraay, J. M. Bijen, and Y. M. De Haan, "The reaction of fly ash in concrete. A critical examination," Cement and Concrete Research, vol. 19, no. 2, pp. 235-246, 1989.

[20] K. G. Babu and G. S. N. Rao, "Efficiency of fly ash in concrete with age," Cement and Concrete Research, vol. 26, no. 3, pp. 465474, 1996.

[21] R. Siddique, Special Structural Concretes, Galgotia, 2000.

[22] S. N. Raman, M. F. M. Zain, and H. B. Mahmud, "Influence of quarry dust and mineral admixtures on the 28th day initial surface absorption of concrete," in Sustainable Development in Concrete Technology: Proceedings of the Seventh International Conference on Concrete Technology in Developing Countries, pp. 33-42, Universiti Teknologi MARA, Kuala Lumpur, Malaysia, 2004.

[23] R. S. Naidu, M. F. M. Zain, and K. S. Tan, "Strength and elasticity of concrete incorporating quarry dust and mineral admixtures," in Proceedings of the 3 rd International Conference on Advances in Strategic Technologies, pp. 1179-1184, Kuala Lumpur, Malaysia, 2003.

[24] IS: 8112-1989, Specification for 43 Grade ordinary Portland Cement, Bureau of Indian Standards, New Delhi, India, 1989. 
[25] IS 4031-1996, reaffirmed 2005, Indian Standard Method of Physical Tests for Hydraulic Cement.

[26] IS: 3812-2003, Specifications for Fly Ash for use as pozzolona and admixture.

[27] IS, "Specification for coarse and fine aggregates from natural sources for concrete," Tech. Rep. IS: 383-1970, 1970.

[28] IS 10262: 2009, Indian standards recommended Guidelines for concrete mix design.

[29] EFNARC, Specification and Guidelines for Self-Compacting Concrete, European Federation of Producers and Applicators of Specialist Products for Structures, 2002.

[30] A. M. Neville, Properties of Concrete: Fourth and Final Edition, Pearson Education Limited, Harlow, UK, 2002.

[31] W. Tangchirapat, C. Rattanashotinunt, R. Buranasing, and C. Jaturapitakkul, "Influence of fly ash on slump loss and strength of concrete fully incorporating recycled concrete aggregates," Journal of Materials in Civil Engineering, vol. 25, no. 2, pp. 243251, 2013.

[32] M. Safiuddin, M. F. M. Zain, M. F. Mahmud, and R. S. Naidu, "Effect of quarry dust and mineral admixtures on the strength and elasticity of concrete," in Proceedings of the Conference on Construction Technology, pp. 68-80, Kota Kinabalu, Malaysia, 2001.

[33] K. S. Tan, M. F. M. Zain, K. M. Yusof, M. Safiuddin, T. Y. Chang, and K. S. Lee, "Influence of quarry dust and silica fume on the properties of high performance concrete," in Proceedings of the 2nd International Conference on Advances in Strategic Technologies, pp. 1563-1572, Bangi, Malaysia, 2000. 



\section{Hindawi}

Submit your manuscripts at

http://www.hindawi.com

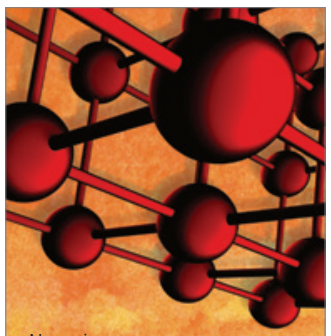

Materials Science and Engineering


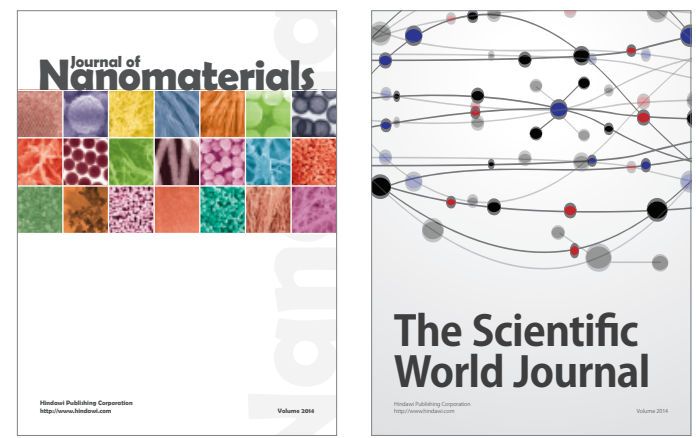

The Scientific World Journal
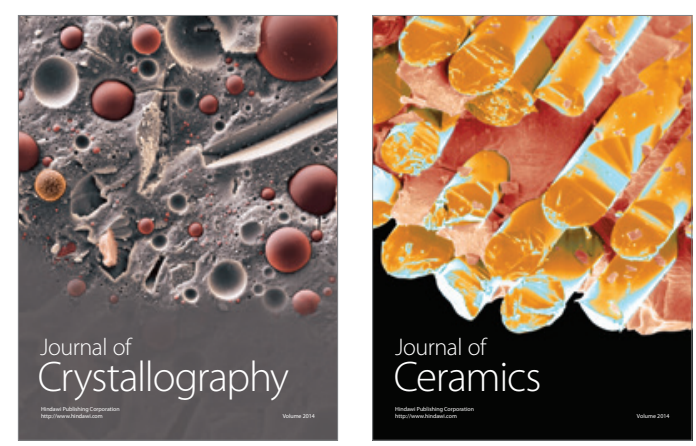
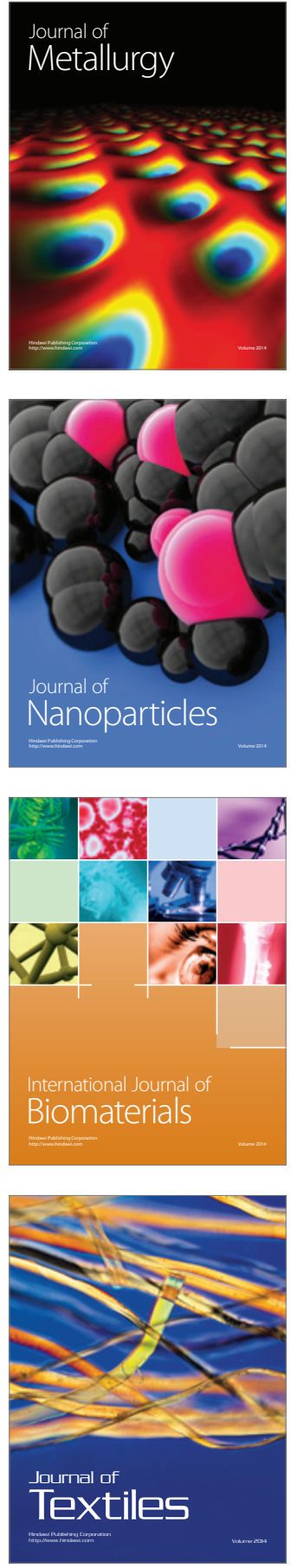